\title{
Sharing pedagogical knowledge between student teacher and her training teacher in the course of pedagogical practice
}

\author{
Kateřina Cásková, Štefan Chudý
}

\begin{abstract}
The aim of this study is to illustrate the pedagogical knowledge through the empirical data from the case study, which emerged in the process of sharing between tutor teacher and future teacher trainee. In the first part, the theoretical basis is defined. Attention is paid to sharing of knowledge, which is realised in the model of apprenticeship. Then the methodology is introduced, the research problem is defined, as well as the design, sample selection, method of data collection and analysis and interpretation. Based on the data analysis, it was found that sharing in the apprenticeship model had an impact on more effective professional preparation. Different experiences of teacher trainer trainers or educators and future teachers often block understanding of the observed or said, because the purpose of sharing is not only to describe what was done in lessons, but in particular to understand what is behind the observed behaviour. Our research has shown that the precondition for sharing is mutual respect and support with regard to the needs of the other. Detailed analysis and description of pedagogical situations enables students to make deeper reflections, which can result in the modification of existing or adopt new elements of practical knowledge to their knowledge base.
\end{abstract}


Keywords: pedagogical knowledge, sharing pedagogical knowledge, apprenticeship, clean language.

\title{
Sdílení pedagogických znalostí mezi studentkou učitelství a její cvičnou učitelkou $\mathrm{v}$ průběhu pedagogické praxe
}

\begin{abstract}
Abstrakt
Cílem této empirické sondy je ilustrovat prostřednictvím dat z případové studie pedagogické znalosti, které vznikly v procesu sdílení mezi cvičnou učitelkou a studentkou učitelství. Nejdříve jsou vymezena teoretická východiska. Následně je věnována pozornost sdílení pedagogických znalostí, které je realizováno v modelu učednictví. Poté je představena metodologie, tedy: výzkumný problém, design, výběr vzorku, metoda sběru, analýzy a interpretace dat. Na základě analýzy dat bylo zjištěno, že sdílení odehrávající se v modelu učednictví má vliv na efektivnější profesní prípravu. Rozdílné zkušenosti cvičné učitelky a studentky mnohdy brání porozumění pozorovaného nebo řečeného, proto smyslem sdílení není jen popsat to, co se v hodinách dělo, ale zejména porozumět tomu, co je za pozorovaným jednáním. Z naší výzkumné sondy vyplynulo, že předpokladem pro sdílení se stává vzájemný respekt a podpora s ohledem na potřeba toho druhého. Podrobný analýza a popis pedagogických situací ze strany cvičného učitele umožní studentce hlubší reflexi, která může vyústit v modifikaci stávajících či přijmout nové prvky praktických znalostí do své znalostní báze.
\end{abstract}

Klíčová slova: pedagogické znalosti, sdílení pedagogických znalostí, učednictví, čistý jazyk.

\section{Introduction}

Students of teaching programmes at university (fututre teachers) acquire knowledge for their professional development not only in theoretical training but also during practical training. Most students may not be aware of the knowledge gained in their preparation for their profession. We believe that this knowledge could be made aware of, and if necessary, modified in the process of sharing, and this could make the training of future teachers more effective. The sharing of practical pedagogical knowledge is based on the mutual cooperation of the teacher trainer trainer with the future teacher and is realised in the apprenticeship model. During this cooperation the teacher trainer trainer analyzes the pedagogical situation by reflecting on his/her experience, which is 
associated in most cases with the problematic situation in which the student's teaching is received or because of the student's professional development stimulating this, from which an impulse to share arises. Thus trainees are given the opportunity to modify existing knowledge in the reflection process throughout this detailed analysis.

\section{Definition of pedagogical knowledge and its sharing}

Knowledge can be defined from the point of view of various disciplines of philosophy, sociology, psychology, pedagogy etc. Due to the fact that this research is situated in the school environment, the subject of the research is sharing pedagogical knowledge between the teacher trainer and teacher trainee, which we define as "a wider cognitive structure that includes theoretical knowledge and practical knowledge" (Janík, 2005, p. 26).

Our attention will be primarily focused on the practical pedagogical knowledge of the teacher trainer trainers, as this knowledge is predominantly the subject of the sharing in practice. Practical knowledge is one that is shaped mainly by experience from teaching practices (Eraut, 1994) and can be projected into the teacher's behaviour. Since the teacher trainee has minimal pedagogical experience, practical knowledge cannot be created as is the case with a teacher trainer trainer. To create practical knowledge, teacher trainees work not only with their own experience in practice but also with sharing knowledge with the teacher trainer trainer.

One area that is often thematized in the context of teacher research is the area of teacher's pedagogical opinions, attitudes, values or beliefs (belief - this is a professional belief, see Píšová, 2005, p. 26), which influences the teacher's behaviour. In the Czech context, the concept of teacher's concept of teaching is used in this context (Mareš, 2013, p.455). If we talk about teacher trainees (future teachers), the term student's concept of teaching is usually used in this context (Švec, 1999, p.39). In the concept of teaching, not only theoretical but also practical knowledge has certain influence. "Teacher's concept of teaching is a complex of pedagogical opinions, pedagogical attitudes and teacher's arguments that justify it. This complex creates a cognitive and emotional basis for teacher's thinking about education, for the assessment of education and teacher's negotiation with all participants in the educational process." (Mareš, 2013, p. 455).

We believe that the concept of teaching is formed even before the beginning of the teacher's career, even before the beginning of the education preparation. The experience of the teacher trainee as a pupil has a strong influence (Richardson, 1996) and so-called apprenticeship of observation (Lortie, 1975). A no less powerful influence on the student's learning is the experience from out - of - school activities. Finally, the teacher trainer contributes to the formation of the concept of teaching as he/she 
shared his/her professional experience and the associated practical knowledge which encourages the teacher trainees. Student's concepts of teaching is a kind of "filter" that enables him/her to process new incoming pedagogical knowledge (Richardson, 1996).

The development and cultivation of pedagogical practical knowledge in pedagogical preparation is influenced by sharing among teaching staff and their trainees. A well-known fact is that students often fail to link the knowledge of theoretical training with practical experience and also often do not understand the practice of the teacher or feedback because they do not know the background of their teacher trainer (Elliott \& Calderhead, 1994). Teacher trainees and their teacher trainer trainers therefore have a different level of practical knowledge, so sharing is more difficult. In this case, the teacher trainee and the teacher trainer trainer enter into a relationship that can be labelled as an apprenticeship.

Our research is based on our previous study (Cásková, 2014, modified). The sharing between the trainee and the teacher trainer takes place in a collaborative model of apprenticeship that combines elements of the traditional and cognitive model of apprenticeship (Van Velzen et al., 2012). The traditional model of apprenticeship lies in the imitation of what the experienced master does. In other words, the teacher shows the student the solutions for pedagogical situations. Observation (or tracking) plays an important role in the traditional apprenticeship process. In pedagogical practice, observation allows students to see general teaching, and this could be a stimulating factor in the learning process of teaching, for two reasons. First, it provides students with an idea of the organization of the individual steps of the lesson before he / she will teach. Secondly, it can help the student understand the feedback from the teacher trainer (cf. Collins, Holum \& Brown, 1991).

In pedagogical practice, the traditional model of apprenticeship, which is based primarily on observation, is insufficient for the student to further develop understanding of a teacher's behaviour, so it is important to promote this understanding through the cognitive model of apprenticeship (Collins et al., 1991). The cognitive model of apprenticeship is different from the traditional one as the traditional model can observe individual steps leading to the successful accomplishment of the task, whereas when learning how to teach this is not always valid, and it is important to complement the discussions about its justification ie "making thinking visible" (Collins et al., 1991 ). This model has been extended to a model of collaborative apprenticeship (Glazer \& Hannafin, 2006), which is based on the mutual interaction of both participants. The model inspired Van Velzen et al. (2012), who pointed to the problem of novice teachers lacking practical knowledge. In their development, they are assisted by the teacher trainer, because this knowledge cannot be obtained other than by practical experience. Collaborative apprenticeship allows the teacher trainee to gain access to the everyday experience they encounter in practice. The teacher trainer analyzes and explains in detail the way in which the pedagogical situation is based on experience, this may 
give the trainee a stimulus for critical reflection of the situation, while opening the door for learning to teach.

If a student reflects any fact, this reflection is probably triggered by some experience - a first-order personal experience- conceptualizing it in conjunction with current experience translates it into a so-called second-order experience. The student finds a connection between the past experience and the present experience by the teacher trainer's behaviour or by the analysis of the situation, and by reflecting it in relation to another context, the student elevates it to a higher abstract level (Shulman 1996, p.209). This approach is understood as an analogy to Korthagen's (2011) view of teacher's career development from gestalt (past experience expressed as a metaphorical gestalt) to the schematization of personal practical knowledge and from schematized personal practical knowledge to formal theory. In both approaches, the current experience of the student in the practice serves to create general proposals, which can be verified in practice in other pedagogical situations.

A teacher trainer can be a bridge between the student's experience and generalized practical constructs or theory, making theories easier for students to grasp. By observing the student's behaviour, the trainer can reveal his/her concept of teaching, and the consequent link to his/her role as a teacher - first-order teaching, which reflects towards the positive career development of the student/teacher trainee. This reflection is a transition to the so-called second-order teaching, that is, the role of teacher as a future teacher (Murray \& Male, 2005). In order to share and thus extend the student's knowledge base, the teacher trainer should (according to Shulman \& Shulman, 2004):

a. have a well-developed vision for the development of the teacher trainees; should be able to communicate and analyze their convictions, assumptions and judgments and relate them to the pedagogical context and thereby create space for students' critical reflection,

b. be respectful to student's needs and be respected by the student,

c. combine theoretical and practical knowledge that are highlighted in student's engagement.

\section{Methodology}

The aim of the study is to find out in which way the sharing of pedagogical knowledge between the teacher trainee and the teacher trainer is taking place within their pedagogical practice.

The research examines:

How pedagogical knowledge is shared between the teacher trainee and his/her teacher trainer? 
Due to the complexity of the concept of sharing of pedagogical knowledge, a qualitative approach was chosen. A research study by Švaříček \& Šed’ová (2007) was chosen as a research design that enabled us to fulfill our goals; to capture the process of sharing pedagogical knowledge between the teacher trainee and his/her teacher trainer.

The sharing of practical pedagogical knowledge takes place in the apprenticeship model. Our research is based on a collaborative apprenticeship model by Van Velzen et al. (2012), which focuses on the sharing of practical pedagogical knowledge in the framework of the co-operation of a teacher trainer with a student of teaching (teacher trainee), but in our research we are based on a certain modification'.

The research was carried out at a primary school in Brno, Czech Republic. The student $^{2}$ and the teacher trainer ${ }^{3}$ were selected on the basis of their voluntary decision to participate in the research, the selection was in the subject of mathematics. In the Czech environment, in the context of practice management, the term facultative teacher or teacher trainer are most often used (with a difference in professional preparedness to practice) (Píšová, 2005), therefore we have decided to use the term "teacher trainer". The research was in agreement with its ethical aspect. Both the teacher trainer and the teacher trainee were acquainted with the course of the interviews as well as with the research. With respect to anonymity, the student performs in a research study under the fictitious name of Ivana. The content of the research interviews was tied to pedagogical practice $^{4}$ that the trainee graduated from within her studies.

\section{Data collection and analysis}

The data for this case study was collected primarily through in-depth interviews for one and a half years. Most of the interviews were focused on the termination of first-person

\footnotetext{
The co-operation of the teacher trainee (future teacher, or the student of pedagogy) and a teacher trainer trainer involves three consecutive phases. At first, the student observes the class of the teacher trainer trainer and follows her actions, such as interacting with pupils, organizing the class etc. Thereafter, the teacher trainee takes the real teacher's role. The lesson is being prepared by the trainee with the help of the teacher trainer trainer. The student is teaching the class, the teacher trainer trainer observes her activity. The lesson is followed by an analysis of the lesson by the teacher trainer trainer, in the form of a discussion. The student receives recommendations or comments from the teacher trainer trainer. In the third phase, a student usually prepares a lesson plan for his/herself, which s/he then practically realizes, again in the presence of the teacher trainer trainer.

2 Teaching as a follow-up Master's programme of teaching mathematics and arts.

3 The teacher trainer has 27 years of teaching experience, she has studied mathematics and biology, and she teaches mathematics and natural science at the lower secondary level at the elementary school.

4 Pedagogical practice at the Faculty of Education of the Masaryk University in Brno in the follow-up Master's programme is for three-semesters: the first and second semesters are continuous; in the third semester the practice is continuous (4 weeks). However, the student teaches only 3 lessons in one subject in his/her first practice, 10 lessons in one subject during the second practice. In the third practice, the student teaches 20 hours.
} 
experience (Varela, Thompson, \& Rosch, 1993), led by a researcher in an inductive way and inspired by the pure language method (Lawley \& Tompkins, 2000).

Data was obtained:

- through direct observation of the teaching of the teacher trainee and the teacher trainers by interviews R1-R7,

- In-depth interviews R1-R10 (January 2014 - May 2015), the average length of which was about 1.5 hours, and except for the first two the rest were recorded on video,

- a reflective diary of the teacher trainee who is tied to pedagogical practice 1.

The time sequence of the interviews was first aimed at finding out the concept of teaching before entering the practice where the research was conducted, then what pedagogical knowledge was the subject of sharing during practice, and finally whether there has been a shift in the formation of the concept of teaching of the student/trainee after graduation.The last interview was retrospective, the structure of this last interview was that the researcher first asked the following open question: What changed after the practice? And he let the student talk freely and then compared his findings with the student's testimony.

Realized interviews ${ }^{5}$ are literally rewritten in the Videograph programme (Rimmele, 2002). Subsequently, their analysis was performed by open coding (Švaříček \& Šed'ová, 2007) with the support of Atlas.ti and the key themes were sought. Interview topics have been studied in context, although they may have occurred remotely in one interview or later in other interviews. The interviews and the topics identified therein have been constantly compared (Švaříček \& Šed’ová, 2007).

\section{Research results}

The study results that are loosely linked and expanded (Cásková, 2015) will be presented in the following section.

\subsection{How does sharing pedagogical knowledge take place through mutual observation of teaching}

In this chapter, attention will be focused on how to share pedagogical knowledge related to the concept of student's education. When observing the teacher trainer, the student reflected her experience on the basis on which she formed her theoretical

5 In the interviews, we refer to individual participants as Researcher, teacher trainer trainer, student or Ivana accordingly. In square brackets, a commentary from the researcher is given. 
schemes. The researcher asked Ivana for a "good relationship" that plays an important role for her.

Researcher: Now, when you say a good relationship is important, between the pupil and the teacher, the important word is good, so in your case, what is a good relationship?

Student: I do not know, I have had a chance to have a lot of observations recently. I think that there was a lot of deficiency in how pupils perceive teachers. If they simply perceived the teachers as cool and a natural authority, they just worked and it was not a problem [it is based on the lessons of her teacher trainer, who she perceives as a natural authority]. But if a teacher who was a little strict, perhaps very authoritativethe pupils just had a block or little respect for him (teacher). So they seemed to be building their aversion to the subject from the beginning, and they were deliberately disturbed [as a result of observing the teaching of another teacher the student had been able to see before entering the school where the research took place]. R10

The student realized that the authoritative behaviour of the teacher did not lead to the achievement of educational goals, and we believe that it also started the process of learning and this is the beginning of understanding the importance of class management. This negative experience has been so emotional to the student that she has been reflecting it several times using metaphors even in her diary, where she is more open ("aggressive", "pupils strike fear", "the atmosphere could be cut" ... and the question arising is "How do I get rid of the fear of the lesson?"), she returns to the topic several times in other interviews. Depending on the atmosphere in the classroom and the teacher's relationship with the pupils, the personality of the teacher is categorized. ${ }^{6}$ We believe that observing the teacher's practice has enabled the student to grasp the concepts of theoretical teaching by associating them with experience in practice.

Another benefit of the observations is the fact that the teacher trainer knows the pupils. Before the following demonstration, Ivana had listened to feedback from the teacher trainer, and then there was a conversation between the researcher and the teacher trainer.

Researcher: So I wanted to ask what interests you based on everything you heard, what did you say to yourself, when did you think something like: I was interested in this, is that good?

Student: I think it is very beneficial that the teacher knows that the children and he/she knows what to expect from them. R4

Benefits can be seen in the teacher's readiness for potential pupil errors or pupil's reactions. The teacher trainer gave her an idea on the organization of the individual steps of teaching before she began teaching, which became a stimulus for reflection and a prerequisite for developing professional thinking. The conversation continues.

6 Some refer to "natural authority", other "authoritarian" or "liberal". 
Researcher: So, the teacher trainer, helped you in the sense that she knows the kids. Did she give you some kind of motivation?

Student: Well it's motivating for me to see the lesson, the style of the teacher because I can learn from it, it's from life, just from the practice. Otherwise, there may be other communications, such as how does the teacher communicate with pupils, how she explains the content of the lesson, as a whole persona. R4

The following R6 demonstration followed Ivana's taught lesson. The teacher trainer first reflects on Ivana's teaching in general, then an interview between Ivana and a teacher trainer takes place, which the researcher continues in order to find out how Ivana understood what was said.

Teacher trainer: [...] The lesson today lacked dynamics, I might have put a more theatrical approach, more like that ... So it would probably be from me, and if you still want to ask something or do you want to discuss it or say your point of view?

Student: It was I messy for me today, like the lesson. I was wondering if the kids are capable of understanding if I do not explain it so much.

Teacher trainer: [jumps to speech]. Well, no, but you know if you did the breaks there, somehow it ended and just closed it, that part. It went so smoothly and merged, and it may have been confusing for the slower ones, it was that it was so loosely passing onto the second example and the second issue that they did not have enough time to finish and they did not know where they were ... I would probably just go there ... yeah ... it's really to split the lesson dynamically like that.

The teacher trainer provides her recommendations in line with the needs of the student, analyzes the development of the situation and explains its pitfalls. She points out the feedback on the basis of how she would have preserved herself in the given situation. The teacher trainer refers to her practice by using a metaphor of "theatre".

Later in the interview, the researcher asks for a "dynamic split of the lesson".

Researcher: [...] So I still have a note that the teacher has used the phrase dynamically break at some moment in the lesson, so what does this mean to you?

Student: Not to speak monotonously. I think it can have a connection with that award, just use some theatrics, just work more with the voice.

Researcher: Do you think it will have any benefit for you?

Student: Yeah, I think this will make sense, and I think it's very important for the kids. [from Ivana's reflection is clear that she realized the importance of "theatre" with respect to pupils, we think because of establishing a relationship with the pupils].

Researcher: When I get back to what we've been discussing... So for you, what would you like to try to include in the future from what the teacher told you about or what we were talking about here?

Student: In the lesson create a relationship with the kids, get to know them to start with some theatrics or something. I know that's what I need, I have the experience that it simply works, just put it somewhere in the school environment. R6 
We think that Ivana recalled past experiences of leisure activities based on observation and then teacher-formulated by the "theatre" metaphor, which became a stimulus for reflection. So the student has probably moved in thinking from her experience (which expresses metaphorical gestures) that she abstracts in relation to another context (school) and thus shifts in her process of learning the teaching. So far, she does not know how to transfer her experience to the school environment, she understands recommendations and looks for concepts to grasp the essence of the classroom management strategy, for the time being abstracts them in using the "theatre" metaphor. We believe this fact has become a challenge for her (Minaříková \& Pravdová, 2016), which she will try to fulfill in her future practice. The teacher trainer enters the interview with her commentary that reflects her experience and explains this vision and points to the student's positive career development.

Teacher trainer: If I work with children and I know them very well and I'm already older. So I can afford the theatrics more because I'm in front of them. I will not get humiliated as much as a young person they do not know much about it. It's more difficult for Ivana, I can afford any shouting, panting, banging on the board. They are laughing and it is an extraordinary situation for them and I have either acclaimed success or an accentuated failure and know that there is a border here. If Ivana does it, if she overdoes it, then there are pitfalls; as the student-teacher trainee the kids do not know her and she may feel embarrassed or if the kids react to it, and she does not know now if it was good or wrong. So it is clear that the student will not exaggerate if the children do not know [the teacher trainer foresees the possible pitfalls of Ivana's position in practice, learning from her experiences with the pupils]. R6

In the extract we can also see the respect of the teacher trainer for the needs of the student. Based on this, we assume that the student understands and absorbs this explanation, as will be seen in the next demonstration.

The barriers between researcher and the student have been abolished with increasing number of talks. What emerged during the last interview of R12 was that Ivana responded more openly, more specifically, and the ideas were systematically organized. We can see a gradually formed schema from the original metaphorical gestalt. In an extract of the interview, she describes the teacher trainer as a natural authority, who even becomes a model for her. By schematizing her previous experience, she is shaping her theorythat the positive relationship of pupils with the teacher which has an influence on the motivation for the learning process, is important.

Researcher: What was important to you with regards to feedback?

Student: So my first formula was the teacher on the practice and that she really did manage those pupils - to communicate, and those pupils loved her while being a natural authority. There was no authoritative type [she critically reflected this experience] and it really was like she knew how to handle the pupils. So for me, the most important thing was probably the point of view from the observation, just as if her approach to the pupils was as if she was on her side and then warmth 
on the part of the pupils. I do not know but they have a simple built relationship, and I liked it [noticing the relationship of the teacher trainer with the pupils - see the demonstration of her teaching concept]. I think the lesson can developped from that point. I do not know, so maybe it came to me as a natural lesson. And then it was important to me that I wanted to achieve that in my classes. Because I think that then the matter can be dealt with in a different way, because as it is going to be fun, they will learn [despite the interest of the pupils to get to the interest of the subject-transition from the first order experience to the second order experience] it was just lessons with the guys like football players, so it was just plain to see, the boys just hanging out with their eyes on the teacher, just like they swallowed every word from her. And although there were certain funny moments in its own way, they took it as if someone else said it and seemed to have missed it as if it were a teacher, they might laugh a lot [it can be assumed that this reflection is taken from teacher trainer], but it just happened there. R12

From the first part of the sentence, "the first formula ...", we can conclude that, after intensive cooperation with the teacher trainer, she moves from the emotional to the so-called second-order experience (the school environment) using metaphors. She basically schematizes her current experience, which is based on so-called metaphorical gestats, and by reflection she shapes her concept of teaching. She finds out that the approach of "natural authority" leads to motivation to learn in pupils, the result of which is a collaborative class with fulfilled educational goals, all of which is built and understood in the context of her initial concept of teaching.

By sharing with a teacher trainer she theoretically defined her desired teacher's self (cf. Pravdová, 2014, pp. 119-135), that is, how she wants to behave in the role of a teacher, literally saying "it was important to me that I wanted to achieve in my class" and so transfer it to my future practice. She wants to achieve a good relationship with pupils, communicate with them i.e being a "natural authority", this good "class management strategy" gives prerequisites to motivate pupils to the subject and it affects the learning of the curriculum. It is likely that if the "class management strategy" were pointed out in relation to that situation, we would be closer to grasping this theoretical construct.

\subsection{Reflection of the teacher trainer in relation to Ivana's concept of teaching}

In the next part the reflection of the teacher trainer will be shown and her relation to the student's concept of teaching. At the beginning of the practice and during the first joint interview, the teacher trainer positively evaluates Ivana's teaching practice.

Teacher trainer: In the introduction part, I liked that there is a relationship between you and the kids, I liked that you asked for the last job what you are interested in about them, it is positively attuned, I think it was really nice. R4 
The teacher trainer reflects on the existence of the relationship between the pupils and Ivana, which is reflected in Ivana's actions, she recognizes the essence of her conception of teaching.

Another passage that the teacher trainer reflects on and which underlines the relationship with pupils is a positive, non-stressful atmosphere in the classroom that again reflects Ivana's concept of teaching.

Teacher trainer: What I envy is your very balanced calm atmosphere, very pleasant all the time, non-stressful, nor do you look that you are neither too excited nor too desperate, and especially important, the children are not getting any stress. R4

Ivan also notes the atmosphere in the classroom in her diary. She evaluates the lesson of art education, which she had the opportunity to see in contrast with the teaching of Czech, she participated in both in the beginning of her pedagogical practice. The researcher, in interview R1, is asking about the atmosphere in the classroom.

Researcher: Here you write about the atmosphere of the art lesson. The atmosphere was relaxed, the pupils listened to music, the pupils were working or talking. What is atmosphere for you?

Student: Well, the atmosphere is sort of how everything is going, how the pupils feel there, and whether they feel some pressure on the part of the teacher, it will be transferred to them as well. E.g. they will not work if the Czech language teacher is predominantly aggressive, so they will not work. When the teacher has a kind approach to them, pupils do not feel under pressure, and I think pupils work better. R1

It is clear from the excerpt that there are two different experiences, both of which are conceptualized towards educational goals. The student notices the uncooperative behaviour of the pupils, which is caused by the inappropriate behaviour of the teacher (cf. Cangelosi, 1994) and thus the process of learning was conducted.

In another example, the teacher trainer highlights and commends the empathy among the pupils and Ivana, explaining the implications for their reaction.

Teacher trainer: First of all, it is her nature that she is really calm. And she does not seem to offer the situations they (pupils) would have to deal with by some emotional speeches. I'm glad to be their class head teacher, really ... discipline with no problems. In any lesson there was not a situation that it would be out of the hands. I think even the feeling that you are basically the pupil, even for me, they know I'm sitting there, making some notes, so I think there's that empathy ... I think a lot of the nature of Ivana, because they know her from art, if they do not mislead and do not feel like she ever embarresed anyone. She did not even mark something negatively, the signs were more motivational, never harmful, instead she behaves kindly. So they (pupils) feel like she is a person who does not deserve ill-treatment. R4

The teacher trainer positively reflects Ivana's behaviour in teaching pupils, she is able to read the student's concept of learning with her attitudes and direct her explanations 
and comments with respect to her needs, thus opening up space for grasping new knowledge and including these in the knowledge base.

Later in the interview R4 Ivana herself elaborated on the topic that "children are sensitive and receptive". The reaction has prompted the researcher's question of the veracity of man.

Student: The child is generally very receptive to such stimuli, a child can feel like a lot. There is an important fairness and certain rules given, but I think the child perceives the person as a person. Those rules, if I agree with them, I have to adhere to them, if I say something once, so it must be true. I can not approve of someone else and do it in some other way. R4

The teacher trainer evaluates Ivana's fair and empathic attitudes towards the pupils and the evaluation of the teacher trainer by Ivana is fair and empathic as well. Even this concept of teaching is evident in her behaviour. In the next chapter we will attempt to summarize the results of the research.

\section{Summary of results and conclusion}

During teaching practice, both Ivana and the experienced teacher trainer shared their pedagogical knowledge, in particular, practical pedagogical knowledge. The research survey was focused on sharing, which was based on mutual observation of lessons and their subsequent reflection. To the observation of Ivana's lesson the teacher trainer responded with her commentary or recommendations. Ivana looked at her teacher trainer's teaching (lessons) using her own views of perceiving teaching process. Ivana reflected her attitudes to these topics, based on her previous experiences of her first order experience, when she was engaged in free time activities and conceptualized them in the context of updates with second-order experience (Shulman, 1996). The teacher trainer made recommendations for those situations that appeared to be problematic or those that were positive to Ivana's further professional development. These recommendations or comments addressed to Ivana, she formulated based on her many years of experience with respect to Ivana's concept of teaching (Shulman \& Shulman, 2004).

In the following part, we will try to answer the above-mentioned research question.

The form of her (trainee) desired teaching self is based on the help of sharing with the teacher trainer (cf. Pravdová, 2014, pp. 119-135), in other words, how to behave in the role of the teacher. She would like to create a good relationship with pupils, i.e be a natural authority, because it gives prerequisites to motivate them to the subject interest and it affects the learning of the curriculum. It was interesting to find out that the student may not even realize that what she would like to achieve in her future teaching is already reflected in her behaviour. This claim is based on the fact that it spontaneously emerged from the observation of the student's teaching and was highlighted by 
a teacher trainer who was not in any way encouraged to do so, and which confirms that the concept of teaching is reflected in the action (Mareš, 2013).

\section{How is the sharing of pedagogical knowledge shared between the teacher trainee and his/her teacher trainer?}

When sharing the behaviour of the teacher trainer becomes an incentive to be aware of, the experience one (trainee) comes to practice. These the trainee reflects and thus modifies, if necessary, in accordance with his/her teaching. This is followed by a phase of cooperation in which, based on his/her long experience, the teacher trainer comments on the student's teaching or recommends her/him the direction of her/his positive career development. The teacher trainer identifies the situation, details it and analyzes it in relation to their further development. It is this description and its analysis that contributes to the student's deeper reflection, the awareness of past experience and connection to the present, all contributing to the approximation of practice and theory. A detailed description of the pedagogical situation brings the student new knowledge or modifies the existing one if he/she finds a link to past experience. This situation is a reference point, therefore a higher level of abstraction (schematization of the situation) and possible integration into his/her knowledge base (Korthagen, 2011).

During pedagogical practice, both the student and the teacher trainer respected each other and aligned each other with the other's goals and needs. The teacher trainer provided the student with a detailed analysis of the situations, anticipated the development of the situation on the basis of her teaching. This mutual respect and support has become a prerequisite for sharing current experiences and has opened up scope for eventual modification in the concept of teaching.

The described qualitative research was focused on sharing the pedagogical knowledge of the teaching of a teacher trainee and her teacher trainer. Sharing can be considered as one of the main activities carried out in the course of teacher training. Typically, what was shared was what and took place in the classroom of a student and a teacher trainer and how this worked. So, what the teacher trainer observes at the student's classes and what the student sees in the classes of the teacher trainer. The difference lies in the fact that the teacher's experience is greater than the experience of the student in practice. Therefore, the purpose of sharing is not just to describe what is happening in the lessons, but especially to understand what is behind the observed behaviour. Our research probe has shown that sharing with a detailed analysis of pedagogical situations by a teacher trainer enabled the student to modify existing or accept new elements of practical knowledge into his knowledge base and to help bring practice and theory closer together. 


\section{Acknowledgment}

The study was supported by the Specific Research Project IGA_PdF_2018_016. The process of designing a teacher's professional identity. The author is very grateful to Mgr. Katerina Lojdová, Ph.D., for the support and valuable remarks that helped to create this study.

\section{References}

Cangelosi, J. S. (1994). Strategie rízení trídy. Praha: Portál.

Cásková, K. (2014). Sharing tacit knowledge among teacher students and their educators during pedagogical practice. In Švec, V. (Ed.), Knowledge Base of Teaching, p. 97-115. Brno: Masaryk University.

Cásková, Kateřina (2015). Sharing tacit knowledge between a student teacher and a teacher trainer. In 2nd International Multidisciplinary Scientific Conference on Social Science and Arts SGEM 2015. Volume II, Education and Educational Research. with. 893-900. Sofia: STEF92.

Collins, A., Holum, A., \& Brown, JS, (1991). Cognitive apprenticeship: Making thinking visible. American Educator, Winter. Available from http://www.21learn.org/arch/articles/brown_seely.html.

Čáp, J. \& Mareš, J. (2001). Psychologie pro učitele. Praha: Portál.

Elliott, B. \& Calderhead, J. (1994). Mentoring for teacher development: Possibilities and caveats. In McIntyre, D., Hagger, H. \& Wilkin, M. (Eds.), Mentoring: perspectives on school-based teacher education, p. 169-189, London: Kogan Page.

Eraut, M. (1994). Developing professional knowledge and competence. London: The Falmer Press.

Glazer, E., M., \& Hannafin, M., J. (2006). The collaborative apprenticeship model: Situated in school settings. Teaching and Teacher Education, 22, 179-193.

Janík T. (2005). Znalost jako klíčová kategorie učitelského vzdělávání. Brno: Paido.

Korthagen, F. et al. (2011). Jak spojit praxi s teorií: didaktika realistického vzdělávání učitelů. Brno: Paido.

Lawley, J., \& amp; Tompkins, P. (2000). Methaphor in Mind: Transformation through Symbolic Modeling. The Developing Company Press.

Lortie, D. (1975). Schoolteacher: A sociological study. Chicago: University of Chicago Press.

Mareš, J. (2013). Pedagogická psychologie. Praha: Portál.

Mareš, J., Slavík, J., Svatoš, T., \& Švec, V. (1996). Učitelovo pojetí výuky. Brno: Masarykova univerzita.

Minaříková, E., \& Pravdová, B. (2017). Pojetí výuky studentů učitelství. Společná témata a individuální výzvy. In Švec, V. et al. Studenti učitelství mezi tacitními a explicitními znalostmi. Brno: Masarykova univerzita.

Píšová, M. (2005). Klinický rok: procesy profesního rozvoje studentů učitelství a jejich podpora. Pardubice: Univerzita Pardubice.

Pravdová, B. (2014). Já jako učitel: profesní sebepojetí studenta učitelství. Brno: Munipress.

Richardson, V. (1996). The role of attitudes and beliefs in learning to teach. In Sikula, J. (Ed.) Handbook of research on teacher education. New York: Macmillan.

Rimmele, R. (2002). Videograph. Multimedia Player zur Kodierung von Videos. Kiel: IPN.

Shulman, L., S. (1996). 'Just in case ...': Reflections on learning from experience. In Colbert, J. A., Desberg, P., \& Trimble, K. D. (1996). The case for education: Contemporary approaches for using case methods. Boston: Allyn and Bacon.

Shulman L., S. \& Shulman J., H. (2004). How and what teachers learn: a shifting perspective. Journal of Curriculum Studies, 36(2), 257-271. 
Švaříček, R., Šed’ová, K. et al. (2007). Kvalitativní výzkum v pedagogických vědách. Praha: Portál. Švec, V. (1999). Pedagogická príprava budoucích učitelů: problémy a inspirace. Brno: Paido.

Tosey P. C., Lawley, J. \& Meese, R. (2014). Methaphor through Clean Language: An innovation in qualitative research. British Journal of Management, 25(3): 629-646.

Varela, F. J., Thompson, E., \& Rosch, E. (1993). The embodied mind: Cognitive science and human experience. Cambridge, Mass: MIT Press.

Velzen, C., Volman, M., Brekelmans, M., White, S. (2012). Guided work-based learning: Sharing practical teaching knowledge with student teachers. Teaching and Teacher Education, 28, 229-239.

\section{Contact:}

doc. Mgr. Štefan Chudý, Ph.D.

Mgr. Kateřina Cásková

Institute of Education and Social Studies

Faculty of Education, Palacký University in Olomouc

Žižkovo náměstí 5, 77140 Olomouc, Czech Republic

Doc. Mgr. Štefan Chudý, Ph.D., head of the Institute of Education and Social Studies, Faculty of Education of the Palacký University in Olomouc guarantees subjects such as theory of educations, philosophy of education and social pedagogy. He is oriented on research into the development of the key competencies of social pedagogues, the preparation of students (i.e. future teachers) and on the resolution of remedial behavioral situations. The field of his scientific research is decision competences, school discipline.

Mgr. Kateřina Cásková is a student of Education doctoral study programme at the Faculty of Education at Palacký University in Olomouc. She currently works as a secondary school teacher. As part of her professional and publishing activities, she specializes in sharing teaching skills between future teachers and teaching staff. 